Check for updates

Cite this: RSC Adv., 2017, 7, 44319

Received 13th July 2017

Accepted 9th September 2017

DOI: $10.1039 / c 7 r a 07710 f$

rsc.li/rsc-advances

\title{
Performance and durability of a layered proton conducting solid oxide fuel cell fueled by the dry reforming of methane
}

\author{
Youmin Guo, (D) *a Tingting Wan, ${ }^{a}$ Ankang Zhu, ${ }^{a}$ Tingting Shi, ${ }^{a}$ Guilin Zhang, ${ }^{a}$ \\ Chunchang Wang, ${ }^{\text {*a }} \mathrm{HaO} \mathrm{Yu}^{\mathrm{b}}$ and Zongping Shao ${ }^{\mathrm{cd}}$
}

\begin{abstract}
Catalyst layers derived from $\mathrm{La}_{2} \mathrm{NiO}_{4}, \mathrm{LaNiO}_{3}$ and $\mathrm{Ni} / \mathrm{La}_{2} \mathrm{O}_{3}$ precursors were applied to a conventional $\mathrm{Ni}$-based anode in a proton conducting solid oxide fuel cell $\left(\mathrm{H}^{+}\right.$-SOFC) for the dry reforming of methane with $\mathrm{CO}_{2}$. The phase structures, microstructures and catalytic activities of catalysts from the different precursors were systematically investigated. The cell performance and durability of a $\mathrm{H}^{+}$-SOFC with a catalyst layer (layered $\mathrm{H}^{+}$-SOFC) were examined. The layered $\mathrm{H}^{+}$-SOFC had higher cell performances than the conventional $\mathrm{H}^{+}$-SOFC. However, catalyst deactivation and degradation of the cell performance were observed as carbon deposition occurred on the catalyst layer due to $\mathrm{CO}$ disproportionation in exhaust gas at a high partial pressure of $\mathrm{CO}$. The structure of carbon deposited on the catalysts was also investigated.
\end{abstract}

\section{Introduction}

Carbon dioxide is a major greenhouse gas that significantly contributes to global warming. To mitigate its impact, technological strategies aimed at avoiding or reusing $\mathrm{CO}_{2}$ emissions are crucial. $\mathrm{CO}_{2}$ dry reforming of methane $\left(\mathrm{CO}_{2}\right.$-DRM), which directly converts $\mathrm{CH}_{4}$ and $\mathrm{CO}_{2}$ into useful chemical products, i.e., syngas, has attracted renewed attention in recent years. ${ }^{1-4}$ However, there are two main drawbacks to $\mathrm{CO}_{2}$-DRM: the large amounts of energy consumed by the $\mathrm{CO}_{2}$-DRM reaction and carbon deposition onto catalysts. ${ }^{5-7}$ The former issue can be effectively solved by electrocatalytic reforming of $\mathrm{CO}_{2}$ with $\mathrm{CH}_{4}$ in a solid oxide fuel cell (SOFC) energy conversion device, which takes advantage of the catalyst material in the anode of the SOFC and generates large amounts of electrical power and syngas. ${ }^{8}$

For in situ $\mathrm{CO}_{2}$-DRM over a SOFC anode, SOFCs based on proton conducting electrolytes $\left(\mathrm{H}^{+}\right.$-SOFC) show outstanding advantages over SOFCs based on oxygen-ionic conducting electrolytes $\left(\mathrm{O}^{2-} \text {-SOFC }\right)^{4,9-11}$ In a conventional $\mathrm{H}^{+}$-SOFC, a Ni-based material is the most attractive choice for the anode because it has a high catalytic activity and comparatively low

\footnotetext{
${ }^{a}$ School of Physics and Materials Science, Anhui University, No. 111 Jiulong Road, Hefei, 230601, China. E-mail: youminguo@ahu.edu.cn; ccwang@ahu.edu.cn

${ }^{b}$ College of Chemical and Environmental Engineering, Shandong University of Science and Technology, 266590, Qingdao, China

'Jiangsu National Synergetic Innovation Center for Advanced Material, College of Energy, State Key Laboratory of Materials-Oriented Chemical Engineering, Nanjing Tech University, Nanjing 210009, China

${ }^{d}$ Department of Chemical Engineering, Curtin University, Perth, WA 6845, Australia
}

cost. However, the conventional Ni-based anode faces problems, including sintering and carbon deposition, which lead to deactivation of the anode when it is used for $\mathrm{CO}_{2}$-DRM. ${ }^{12,13}$ Therefore, both enhancing the resistance of the conventional Ni-based anode to carbon deposition and prolonging its operation lifetime are of great significance.

Deposition of a catalyst layer with high activity for $\mathrm{CO}_{2}$-DRM and good resistance towards coke formation on the conventional Ni-based anode has been proposed to increase the operational stability and performance of SOFC fueled with methane. ${ }^{4,14,15}$ For instance, Wang et al. used a catalyst, GdNi$\mathrm{Al}_{2} \mathrm{O}_{3}$, as a highly coking-resistant layer on the conventional $\mathrm{Ni}$-based anode of $\mathrm{O}^{2-}$-SOFC. The fuel cell with a $\mathrm{GdNi}-\mathrm{Al}_{2} \mathrm{O}_{3}$ catalyst layer had high cell performance and stability. ${ }^{14}$ Additionally, developing a catalyst layer over a Ni-based anode of $\mathrm{H}^{+}$-SOFC has been demonstrated to be an effective solution. ${ }^{4}$ For instance, Hua et al. concluded that a $\mathrm{Ni}_{0.8} \mathrm{Co}_{0.2^{-}}$ $\mathrm{La}_{0.2} \mathrm{Ce}_{0.8} \mathrm{O}_{1.9}$ catalyst layer had superior activity towards in situ dry reforming and improved $\mathrm{CO}_{2}$ resistance to that of the conventional Ni-base anode. ${ }^{4}$ Moreover, Verykios et al. have proved that using Ni-based catalysts with strongly basic alkaline oxides as supports can suppress carbon deposition. ${ }^{16}$ Various supports, including $\mathrm{ZrO}_{2}, \mathrm{TiO}_{2}, \mathrm{CeO}_{2}, \mathrm{CeO}_{2}-\mathrm{ZrO}_{2}$ and $\mathrm{La}_{2} \mathrm{O}_{3}$, have been used for Ni-based catalysts. ${ }^{17-19}$ Among them, $\mathrm{La}_{2} \mathrm{O}_{3}$ has been demonstrated to be a promising support owing to its possible transformation to $\mathrm{La}_{2} \mathrm{O}_{2} \mathrm{CO}_{3}$ under reactive conditions. ${ }^{16,20,21}$ However, carbon deposition is closely related to a catalyst's structure. ${ }^{21-23}$ Recently, we have demonstrated that $\mathrm{La}_{2} \mathrm{NiO}_{4}$ (LN) perovskite is a potential catalyst precursor of $\mathrm{Ni} / \mathrm{La}_{2} \mathrm{O}_{3}$ for in situ $\mathrm{CO}_{2}$-DRM over a $\mathrm{H}^{+}$-SOFC anode. This crystalline perovskite contains active $\mathrm{Ni}$ homogeneously 
dispersed throughout the bulk. During the reduction process, some Ni metal particles migrate to the surface, resulting in the homogenous distribution of active Ni sites on the $\mathrm{La}_{2} \mathrm{O}_{3}$ support $\left(\mathrm{Ni} / \mathrm{La}_{2} \mathrm{O}_{3}\right)$. By applying this catalyst layer to the conventional $\mathrm{H}^{+}$-SOFC, a $\mathrm{CH}_{4}-\mathrm{CO}_{2}$ mixture was effectively converted to $\mathrm{CO}-\mathrm{H}_{2}$ syngas on the catalyst layer, and then $\mathrm{H}_{2}$ produced in situ was consumed by $\mathrm{H}^{+}$-SOFC, yielding a syngas with a high $\mathrm{CO}$ concentration. Based on the results of an on-line GC analysis, the CO concentration can reach over $60 \%$ in the exhaust gas from the anode. However, according to the results of Luo et al., CO disproportionation occurs on $\mathrm{Ni} / \mathrm{La}_{2} \mathrm{O}_{3} / 5 \mathrm{~A}$ catalysts in a CO atmosphere, leading to the deposition of carbon. ${ }^{24}$ This suggests that the reduced $\mathrm{LN}$ catalyst on the $\mathrm{H}^{+}$-SOFC anode might lead to carbon deposition in a gas mixture with a high CO concentration, which would lead to a decreased catalytic activity and the degradation of cell performance. Thus, it is necessary to further examine the durability of the $\mathrm{H}^{+}$-SOFC with a catalyst layer (called layered $\mathrm{H}^{+}$-SOFC) fueled by a $\mathrm{CH}_{4}-\mathrm{CO}_{2}$ mixture, especially in exhaust gases with high concentrations of CO.

In the present work, perovskite-type oxides in the form of $\mathrm{La}_{2} \mathrm{NiO}_{4}$ (LN-1) and $\mathrm{LaNiO}_{3}(\mathrm{LN}-2)$ were synthesized by the glycine nitrate process (GNP) method and used as catalytic precursors for $\mathrm{CO}_{2}$-DRM over a conventional Ni-based anode of a $\mathrm{H}^{+}$-SOFC. For comparison, $\mathrm{Ni} / \mathrm{La}_{2} \mathrm{O}_{3}$ was also prepared by an impregnation method. The catalytic ability and carbon deposition properties of the catalysts derived from the different precursors were systematically studied. Finally, the cell performance and durability of the layered $\mathrm{H}^{+}$-SOFCs were investigated when using methane reforming as a fuel.

\section{Experimental}

\subsection{Materials synthesis and catalyst preparation}

A sol-gel process was used to prepare $\mathrm{BaZr}_{0.4} \mathrm{Ce}_{0.4} \mathrm{Y}_{0.2} \mathrm{O}_{3-\delta}$ (BZCY4), $\quad \mathrm{BaZr}_{0.1} \mathrm{Ce}_{0.7} \mathrm{Y}_{0.2} \mathrm{O}_{3-\delta} \quad$ (BZCY1) electrolytes and $\mathrm{Ba}_{0.5} \mathrm{Sr}_{0.5} \mathrm{Co}_{0.8} \mathrm{Fe}_{0.2} \mathrm{O}_{3-\delta}$ (BSCF) cathode material for $\mathrm{H}^{+}$-SOFC. Taking the synthesis of BSCF cathode as an example, a stoichiometric amount of $\mathrm{Ba}\left(\mathrm{NO}_{3}\right)_{2}, \mathrm{Sr}\left(\mathrm{NO}_{3}\right)_{2}, \mathrm{Co}\left(\mathrm{NO}_{3}\right)_{3} \cdot 6 \mathrm{H}_{2} \mathrm{O}$ and $\mathrm{Fe}\left(\mathrm{NO}_{3}\right)_{3} \cdot 9 \mathrm{H}_{2} \mathrm{O}$ was first dissolved in distilled water to obtain a transparent solution under heating. Complexing agents of EDTA and citric acid were mixed in distilled water by adding a proper amount of ammonia solution to adjust the $\mathrm{pH}$ value of the aqueous solution to $\sim 8$. Next, the chelating solution was added into the salt solution slowly. The molar ratio of EDTA to CA to the total metal cations content was set at $1: 2: 1$. The solution was heated at $80{ }^{\circ} \mathrm{C}$ and stirred until obtaining a viscous gel. By further heated at $240{ }^{\circ} \mathrm{C}$ in an oven, the gel was converted into a black ash. The synthesized powders were calcined for $5 \mathrm{~h}$ with a heating rate of $5{ }^{\circ} \mathrm{C} \min ^{-1}$. The calcinations temperatures for BZCY1, BZCY4 and BSCF were $1000{ }^{\circ} \mathrm{C}$.

Lanthanum nickel perovskite $\mathrm{La}_{2} \mathrm{NiO}_{4}(\mathrm{LN}-1)$ and $\mathrm{LaNiO}_{3}$ (LN-2) catalysts were prepared by a glycine nitrate process (GNP). Metal nitrates of $\mathrm{La}\left(\mathrm{NO}_{3}\right)_{3} \cdot 6 \mathrm{H}_{2} \mathrm{O}$ and $\mathrm{Ni}\left(\mathrm{NO}_{3}\right)_{2} \cdot 6 \mathrm{H}_{2} \mathrm{O}$ were dissolved with glycine in distilled water at an equivalent ratio of $1: 2$ under stirring. The resulting solution was heated at $80{ }^{\circ} \mathrm{C}$ to form a viscous gel. The obtained gel was dried in an oven at $\sim 250{ }^{\circ} \mathrm{C}$ and ignited to form an ash. The obtained ash was finally calcined in air for $5 \mathrm{~h}$ to achieve a perovskite structure. The calcination temperatures for LN-1 and LN-2 were 900 and $800{ }^{\circ} \mathrm{C}$, respectively.

The $\mathrm{Ni} / \mathrm{La}_{2} \mathrm{O}_{3}$ catalyst, containing $15 \mathrm{wt} \% \mathrm{Ni}$, was prepared by a wet-impregnation method using nickel nitrate as the metal precursor. A weighed amount of nickel nitrate was placed in a beaker, and the appropriate amount of distilled water was added. After $30 \mathrm{~min}$, an appropriate weight of $\mathrm{La}_{2} \mathrm{O}_{3}$ was added under continuous stirring. The mixture was stirred at ambient temperature for $5 \mathrm{~h}$. The obtained slurry was then dried at $110^{\circ} \mathrm{C}$ for $5 \mathrm{~h}$ on an electric heating board. After this treatment, the dried powder was calcined at $800{ }^{\circ} \mathrm{C}$ in air for $5 \mathrm{~h}$.

\subsection{Fabrication of cells}

$\mathrm{NiO}+$ BZCY4 anode-supported BZCY1 electrolytes were prepared by the dry pressing technique described in our previous work. ${ }^{12}$ The NiO + BZCY4 anode was made from a mixture of $60 \mathrm{wt} \% \mathrm{NiO}, 40 \mathrm{wt} \% \mathrm{BZCY} 4$ and $5 \mathrm{wt} \%$ PVB as a pore former. The electrolyte layer was made from fine BZCY1 powders. According to the procedure described in our previous papers, the NiO + BZCY4 anode-supported BZCY1 dual layers were sintered at $1500{ }^{\circ} \mathrm{C}$ for $5 \mathrm{~h}$. Then a BSCF slurry was prepared by adding ethylene glycol, isopropanol and glycerine and ground using a mortar-pestle for $1 \mathrm{~h}$. After that, a cathode layer of BSCF was deposited on the surface of the BZCY1 electrolyte by spray coating and was fired at $1000{ }^{\circ} \mathrm{C}$ for $2 \mathrm{~h}$. The obtained single cell had an effective area of $0.4 \mathrm{~cm}^{2}$. To prepare the layered $\mathrm{H}^{+}$-SOFC, various catalysts were deposited onto the surface of the NiO + BZCY4 anode by spray coating, followed by calcination at $800{ }^{\circ} \mathrm{C}$ for $2 \mathrm{~h}$.

\subsection{Catalyst activity evaluation}

The catalytic activities of the $\mathrm{LN}-1, \mathrm{LN}-2$ and $\mathrm{Ni} / \mathrm{La}_{2} \mathrm{O}_{3}$ catalysts were conducted in a fixed bed reactor, using $0.2 \mathrm{~g}$ of a catalyst mixed with $0.4 \mathrm{~g}$ of silica. The samples were pre-treated in pure $\mathrm{H}_{2}$ with a flow rate of $50 \mathrm{~mL} \min ^{-1}$ at $700{ }^{\circ} \mathrm{C}$ for $2 \mathrm{~h}$ to reduce the perovskite oxides to a system based on $\mathrm{Ni} / \mathrm{La}_{2} \mathrm{O}_{3}$. The $\mathrm{CH}_{4}$ and $\mathrm{CO}_{2}$ reactants (with the ratio of $1: 1$ ) were diluted in $\mathrm{He}$ (10:10:80 by volume) and fed from the top of the fixed bed reactor within the temperature range of $500-700{ }^{\circ} \mathrm{C}$. The reactants and products were analyzed using a gas chromatograph (Varian 3800) equipped with a thermal conductivity detector (TCD). The $\mathrm{CO}_{2}$ conversion and $\mathrm{CO}$ selectivity were calculated via the equations indicated in our previous work. ${ }^{15}$

\subsection{Characterizations}

The reducibility of various catalysts was investigated by hydrogen temperature-programmed reduction $\left(\mathrm{H}_{2}\right.$-TPR $)$ in a BELCAT-A apparatus (BEL Japan, Inc.). Approximately $0.03 \mathrm{~g}$ of catalyst particles were placed in a U-type quartz reactor with an inner diameter of approximately $3 \mathrm{~mm}$. The sample was pretreated under a pure argon atmosphere at a flow rate of $30 \mathrm{~mL} \mathrm{~min}^{-1}[\mathrm{STP}]$ at $400{ }^{\circ} \mathrm{C}$ for $30 \mathrm{~min}$. After it cooled to room temperature, the atmosphere was switched to $10 \mathrm{vol} \% \mathrm{H}_{2} / \mathrm{Ar}$, and the reactor was programmatically heated to $900{ }^{\circ} \mathrm{C}$, with 
a heating rate of $10{ }^{\circ} \mathrm{C} \min ^{-1}$. The amount of hydrogen consumed was monitored by an in situ thermal conductivity detector (TCD).

The specific surface area of the catalysts was characterized by $\mathrm{N}_{2}$ adsorption at liquid nitrogen temperature using a surface area analyzer (BELSORP II, Japan). Prior to nitrogen adsorption, the samples were degassed at $300{ }^{\circ} \mathrm{C}$ for $2 \mathrm{~h}$ to remove any physically adsorbed species. The surface area was determined from the linear portion of the BET equation. The Ni particle sizes of the reduced catalysts were verified by TEM (JEM-2100).

Laser Raman spectroscopy of the various catalysts was performed after treatment at $700{ }^{\circ} \mathrm{C}$ under a $\mathrm{CO}-\mathrm{H}_{2}$ mixture for $10 \mathrm{~h}$ using in an HR800 UV Raman microspectrometer (inviaRefiex) and the green line of an argon laser as the excitation source. Thermogravimetric (TG) measurements were performed in air on the various reduced catalysts after different treatments using a STA 449 F3 analyzer (NETZSCH Instruments Co. Ltd.). Before TG analysis, the reduced catalysts were treated with a $\mathrm{CH}_{4}-\mathrm{CO}_{2}$ mixture at $700{ }^{\circ} \mathrm{C}$ for $10 \mathrm{~h}$ or a $80 \% \mathrm{CO}-20 \% \mathrm{H}_{2}$ mixture at $700{ }^{\circ} \mathrm{C}$ for $5 \mathrm{~h}$.

The powder X-ray diffraction (XRD) patterns of the synthesized and treated catalysts were recorded on a Smartlab $9 \mathrm{~kW}$ diffractometer with a $\mathrm{Cu} \mathrm{K} \alpha$ radiation source $(\lambda=1.5418 \AA)$ at $40 \mathrm{kV}$ and $100 \mathrm{~mA}$. Spectra were collected in the range $2 \theta=20-80^{\circ}$, with a step of $0.05^{\circ}$ and an acquisition time of $1 \mathrm{~s}$ for each point.

The $I-V$ polarization curves of the fuel cells were measured at 500-700 ${ }^{\circ} \mathrm{C}$ using a Keithley 2420 source meter in a 4-probe mode. During the measurements, hydrogen and $\mathrm{CH}_{4}-\mathrm{CO}_{2}$ gas mixtures were separately fed into the anode chamber, and ambient air was used as the oxidant gas in the cathode chamber. The flow rate of hydrogen and the $\mathrm{CH}_{4}-\mathrm{CO}_{2}$ mixture was maintained at $80 \mathrm{~mL} \min ^{-1}$. The durability tests were performed on single cells with various catalyst layers under a constant current load. The corresponding electrochemical impedance spectra (EIS) of the single cells were carried out using a Solartron 1260A. The EIS was monitored under open circuit voltage conditions. The applied frequency ranged from $10^{4}$ to $10^{-1} \mathrm{~Hz}$, and the signal amplitude was $200 \mathrm{mV}$.

\section{Results and discussion}

\subsection{Basic properties of the synthesized catalysts}

One significant advantage of $\mathrm{H}^{+}$-SOFC is that it can operate at an intermediate-to-low temperature range of $400-700^{\circ} \mathrm{C}$. A catalyst coating on the layered $\mathrm{H}^{+}$-SOFC, $\mathrm{LN}-1, \mathrm{LN}-2$ and $\mathrm{Ni} / \mathrm{La}_{2} \mathrm{O}_{3}$ catalysts should be easily reduced at the operating temperature. Therefore, the reduction behaviors of $\mathrm{LN}-1, \mathrm{LN}-2$ and $\mathrm{Ni} / \mathrm{La}_{2} \mathrm{O}_{3}$ were first investigated by a temperature programmed reduction (TPR) technique. As shown in Fig. 1, two peaks were observed for the LN-1 samples, and the main peak at $650{ }^{\circ} \mathrm{C}$ corresponded to the complete reduction of $\mathrm{LN}-1$ to $\mathrm{Ni}$ and $\mathrm{La}_{2} \mathrm{O}_{3}$, which was consistent with previously reported results. ${ }^{25}$ Three peaks at 345,373 and $503{ }^{\circ} \mathrm{C}$ were observed for LN-2 samples. According to the literature,,$^{26,27}$ the first reduction peak at $345{ }^{\circ} \mathrm{C}$ was due to the reduction of $\mathrm{Ni}^{3+}$ to $\mathrm{Ni}^{2+}$, and the third peak at $503{ }^{\circ} \mathrm{C}$ corresponded to the reduction of $\mathrm{Ni}^{2+}$ to $\mathrm{Ni}^{0}$ (metallic nickel), both of which came from the perovskite structure. This

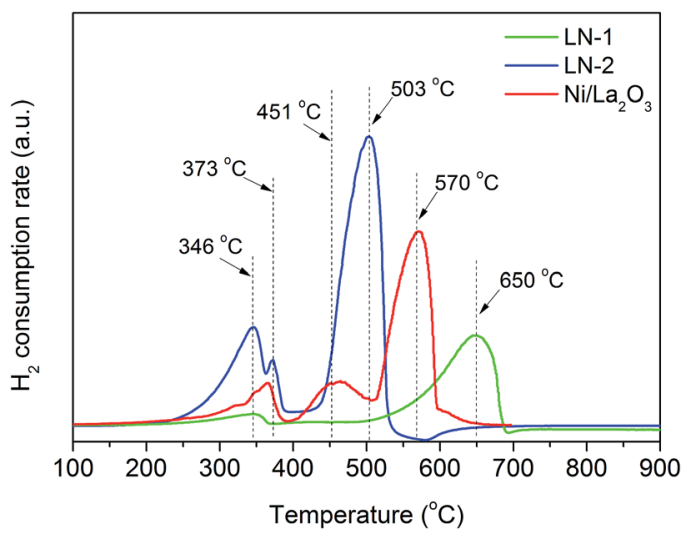

Fig. $1 \mathrm{H}_{2}$-TPR profiles of the $L N-1, L N-2$ and $\mathrm{Ni} / \mathrm{La}_{2} \mathrm{O}_{3}$ samples.

result indicated that the perovskite structure of $\mathrm{LN}-2$ was destroyed and the metallic Ni particles were dispersed over $\mathrm{La}_{2} \mathrm{O}_{3}$. The small peak at $373{ }^{\circ} \mathrm{C}$ can be associated with the reduction of $\mathrm{Ni}^{2+}$ to $\mathrm{Ni}^{0}$ in a $\mathrm{NiO}$ phase. The $\mathrm{Ni} / \mathrm{La}_{2} \mathrm{O}_{3}$ catalyst also showed three reduction peaks. The peaks at 366 and $570{ }^{\circ} \mathrm{C}$ corresponded to the reduction of $\mathrm{Ni} / \mathrm{La}_{2} \mathrm{O}_{3}$, while the intermediate peak was attributed to the reduction of $\mathrm{Ni}^{2+}$ to $\mathrm{Ni}^{0}$ in the LN-2 perovskite structure. ${ }^{28}$ For all the samples, the reduction of $\mathrm{Ni}^{2+}$ to metallic Ni occurred at a high temperature. This TPR experiment confirms that the synthesized samples can be completely reduced at a temperature of $700{ }^{\circ} \mathrm{C}$.

Fig. 2 shows the XRD patterns of the synthesized LN-1, LN-2 and $\mathrm{Ni} / \mathrm{La}_{2} \mathrm{O}_{3}$ catalysts before and after the hydrogen reduction. After calcining, only the $\mathrm{LN}-1$ and $\mathrm{LN}-2$ perovskite structures were observed for LN-1 and LN-2 samples, respectively (Fig. 2a and $b$ ). For the $\mathrm{Ni} / \mathrm{La}_{2} \mathrm{O}_{3}$ sample, aside from the diffraction peaks of $\mathrm{La}_{2} \mathrm{O}_{3}\left(27.0\right.$ and $\left.28.1^{\circ}\right)$, some additional diffraction peaks at $2 \theta=32.8^{\circ}$ were also found. This indicated that the formation of the $\mathrm{LN}-2$ perovskite structure occurred during the high temperature calcination process, which agreed with our TPR results. After reduction under a hydrogen atmosphere at $700{ }^{\circ} \mathrm{C}$ for $2 \mathrm{~h}$, the perovskite structures of $\mathrm{LN}-1$ and $\mathrm{LN}-2$ were completely destroyed and the only detected phases were $\mathrm{Ni}^{0}$ and $\mathrm{La}_{2} \mathrm{O}_{3}$ for all the samples.

The BET surface areas of the synthesized LN-1, LN-2 and $\mathrm{Ni} / \mathrm{La}_{2} \mathrm{O}_{3}$ samples were $2.6,3.0$ and $3.9 \mathrm{~m}^{2} \mathrm{~g}^{-1}$, respectively, which were typical of these materials when prepared from high temperature calcinations. After the reduction, the BET surface areas increased to $13.5,11.3$ and $10.8 \mathrm{~m}^{2} \mathrm{~g}^{-1}$, respectively. To observe the state of $\mathrm{Ni}$ particles on reduced catalysts (before the $\mathrm{CO}_{2}$-DRM reaction), the microstructures of the reduced samples were investigated using TEM. As presented in Fig. 3, the Ni particle sizes in reduced $\mathrm{LN}-1, \mathrm{LN}-2$ and $\mathrm{Ni} / \mathrm{La}_{2} \mathrm{O}_{3}$ ranged from 20-50, 40-90 and 20-50 nm, respectively. Smaller nickel particles were observed in reduced $\mathrm{LN}-1$ than in $\mathrm{LN}-2$, which could be attributed to the lower nickel content in LN-1 than in LN-2. Furthermore, the $\mathrm{Ni}$ species were highly dispersed and uniformly distributed in all the samples, agreed with the results from the XRD analysis. A high dispersion of Ni will likely improve the catalytic activity of the catalysts. 

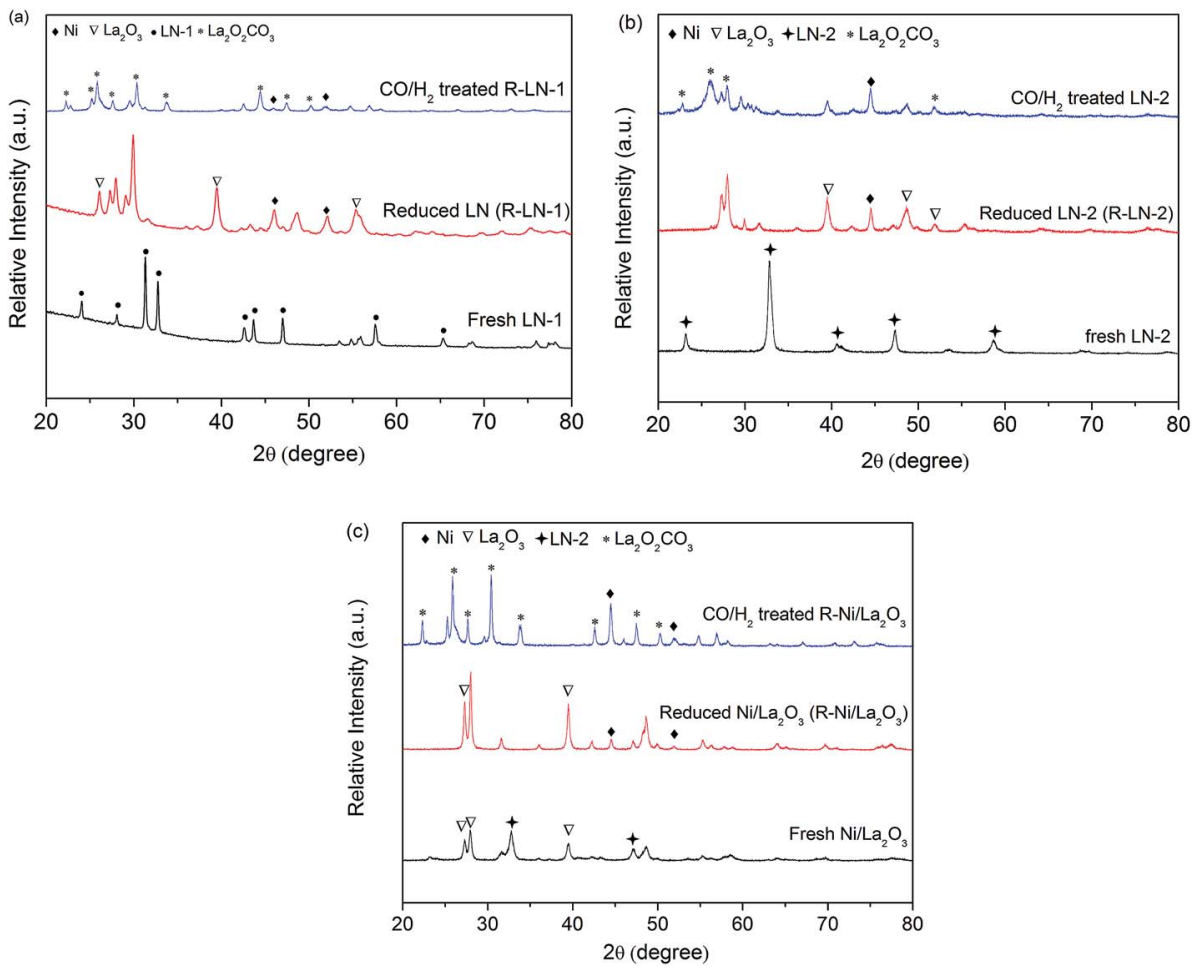

Fig. 2 XRD patterns of the synthesized, reduced and treated samples: (a) LN-1; (b) LN-2 and (c) Ni/La $\mathrm{O}_{3}$.

\subsection{Catalytic activity and cell performance}

Fig. 4 presents stable values for the conversion of $\mathrm{CO}_{2}$ and selectivity of $\mathrm{CO} \mathrm{Ni} / \mathrm{La}_{2} \mathrm{O}_{3}$, which originated from the LN-1, LN-2 and $\mathrm{Ni} / \mathrm{La}_{2} \mathrm{O}_{3}$ catalyst precursors. In the low temperature range of 500 to $600{ }^{\circ} \mathrm{C}$, the reduced $\mathrm{Ni} / \mathrm{La}_{2} \mathrm{O}_{3}$ catalysts showed better catalytic performances than $\mathrm{LN}-1$ and $\mathrm{LN}-2$. However, with the rise in temperature, both $\mathrm{CO}_{2}$ conversion and $\mathrm{CO}$ selectivity increased to similar values. For instance, $\mathrm{CO}_{2}$ conversions and CO selectivity reached as high as $95 \%$ and $96 \%$, respectively, for all of the reduced catalysts at $700{ }^{\circ} \mathrm{C}$. This result indicates that all of the selected precursors are potential catalysts for $\mathrm{CO}_{2}$ DRM and produce $\mathrm{H}_{2} / \mathrm{CO}$ syngas as a fuel for the layered $\mathrm{H}^{+}$SOFC.

The catalysts derived from various precursors were then investigated as a catalyst layer in a single cell with $32 \mu \mathrm{m}$ thick BZCY1 electrolyte. Before feeding fuel into the anode, pure $\mathrm{H}_{2}$ was introduced to reduce the catalyst precursors for $2 \mathrm{~h}$ at
$700{ }^{\circ} \mathrm{C}$. Fig. 5 shows the $I-V$ curves of the layered $\mathrm{H}^{+}$-SOFC fueled by a $\mathrm{H}_{2}$ and $\mathrm{CH}_{4}-\mathrm{CO}_{2}$ mixture at $700{ }^{\circ} \mathrm{C}$. By applying $\mathrm{CH}_{4}-\mathrm{CO}_{2}$ as the fuel, the cell delivered peak power densities of 199, 263, 228 and $209 \mathrm{~mW} \mathrm{~cm}^{-2}$ for bare $\mathrm{H}^{+}$-SOFC and layered $\mathrm{H}^{+}$-SOFC with $\mathrm{LN}-1, \mathrm{LN}-2$ and $\mathrm{Ni} / \mathrm{La}_{2} \mathrm{O}_{3}$ catalyst precursors, respectively, while they were $698,680,659$ and $620 \mathrm{~mW} \mathrm{~cm}^{-2}$, respectively, when pure hydrogen was applied as the fuel. These results showed that the layered $\mathrm{H}^{+}$-SOFC with different catalysts delivered higher cell performances than that of the conventional $\mathrm{H}^{+}$-SOFC in a $\mathrm{CH}_{4}-\mathrm{CO}_{2}$ atmosphere. It further demonstrated that the catalyst layer improved the catalytic activity of $\mathrm{H}^{+}$-SOFC for $\mathrm{CO}_{2}$-DRM reaction and produced the high power outputs.

\subsection{Durability of cell and carbon deposition}

The operational durability of the layered $\mathrm{H}^{+}$-SOFC with different catalyst layers under a specific current density at $700{ }^{\circ} \mathrm{C}$ was studied. As shown in Fig. 6a, under a specific current density of
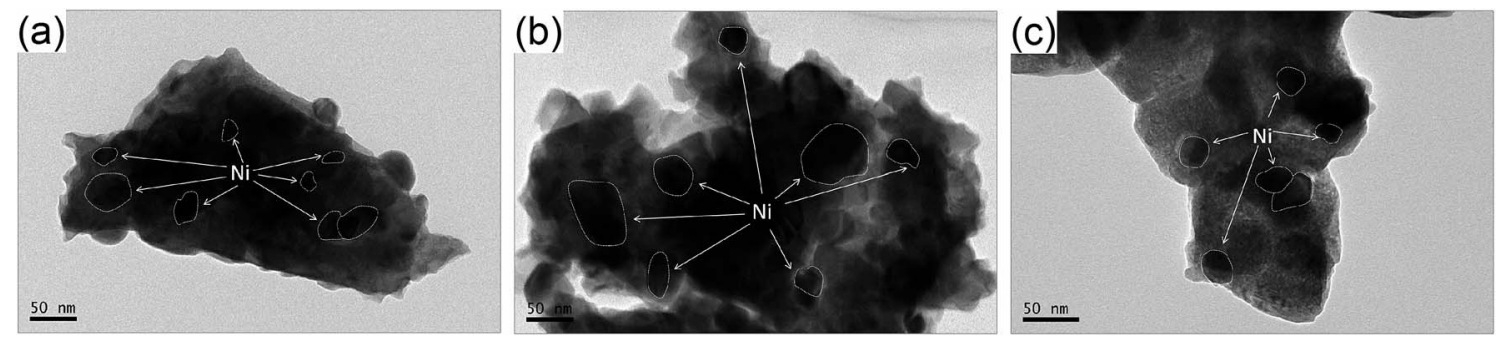

Fig. 3 TEM images of the reduced samples in $\mathrm{H}_{2}$ atmosphere: (a) $L N-1$; (b) $L N-2$ and (c) $\mathrm{Ni} / \mathrm{La}_{2} \mathrm{O}_{3}$. 


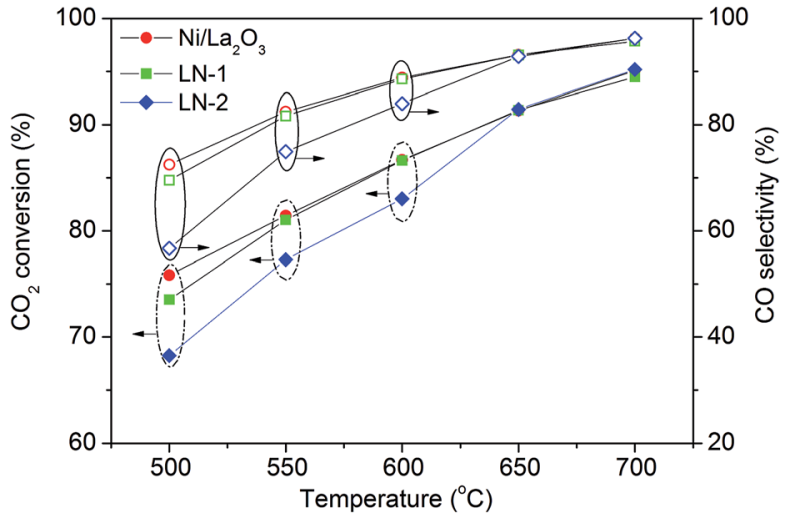

Fig. 4 Conversion of $\mathrm{CO}_{2}$ and selectivity of $\mathrm{CO}$ observed over the reduced $L N-1, L N-2$ and $\mathrm{Ni} / \mathrm{La}_{2} \mathrm{O}_{3}$ samples during $\mathrm{CH}_{4} / \mathrm{CO}_{2}$ reforming at various temperatures. Before catalytic reaction, the catalysts were sintered in air at $1000^{\circ} \mathrm{C}$ for $2 \mathrm{~h}$.

$175 \mathrm{~mA} \mathrm{~cm}^{-2}$, cells with a catalyst layer were much more stable than that without any catalyst. For instance, the voltage decreased $11.9 \%, 15.4 \%, 11.1 \%$ and $19.7 \%$ for the cells with the $\mathrm{LN}-1, \mathrm{LN}-2, \mathrm{Ni} / \mathrm{La}_{2} \mathrm{O}_{3}$ catalyst layer and bare $\mathrm{H}^{+}$-SOFC in the first 4 hours, respectively. By increasing the operation time, the voltage of all the cells continued to decrease. The voltage of bare $\mathrm{H}^{+}$-SOFC started to decrease sharply, leading to a terminal voltage of zero. All the layered $\mathrm{H}^{+}$-SOFCs decreased slowly compared to bare $\mathrm{H}^{+}$-SOFC, especially for the cell with the $\mathrm{Ni} / \mathrm{La}_{2} \mathrm{O}_{3}$ catalyst layer. To clarify the effect of the catalyst, the ohmic resistance of the electrolyte and overpotential resistances of the electrodes for the fuel cells operated with $\mathrm{CH}_{4}-\mathrm{CO}_{2}$ mixture gas were calculated according to the electrochemical impedance spectra (EIS) for the fuel cells. In calculation, the intercept at high frequency was used for ohmic resistance of the electrolyte $\left(R_{\mathrm{o}}\right)$, and the difference between the low frequency intercept and the high frequency intercept on the real axis was used as the overpotential resistance of the electrodes $\left(R_{\mathrm{p}}\right)$. Fig. $6 \mathrm{~b}$ shows the corresponding values at the initial stage and after the stability test for 6 hours. Because the cathode for all the fuel cells were same and operated in air atmosphere, the increase in overpotential resistance can be ascribed to the anode part. It demonstrated that both the $R_{\mathrm{O}}$ and $R_{\mathrm{p}}$ increased obviously after the stability test for 6 hours, especially for the bare $\mathrm{H}^{+}$-SOFC. This finding agrees well with the degradation of the fuel cell performance in Fig. 6a. As mentioned above, when the $\mathrm{H}_{2}$ in the produced $\mathrm{H}_{2} / \mathrm{CO}$ syngas was consumed as a fuel by the layered $\mathrm{H}^{+}$-SOFC, the reduced catalysts were exposed to a $\mathrm{H}_{2} / \mathrm{CO}$ mixture with a high partial pressure of CO. This high $\mathrm{CO} / \mathrm{H}_{2}$ ratio could lead to carbon deposition via the $\mathrm{CO}$ disproportionation reaction $\left(2 \mathrm{CO} \rightarrow \mathrm{C}+\mathrm{CO}_{2}\right)$ and result in catalyst deactivation and degradation of cell performance. ${ }^{29}$ Thus, this degradation may be caused by the severe coke buildup on the anode that was visible to the eye after the test.

To investigate the carbon deposition on the reduced catalysts of the layered $\mathrm{H}^{+}$-SOFC in a gas mixture with a high $\mathrm{CO} / \mathrm{H}_{2}$ ratio, the catalysts were treated in an $\mathrm{H}_{2} / \mathrm{CO}$ atmosphere $(1: 4$ in vol\%) at $700{ }^{\circ} \mathrm{C}$ for $5 \mathrm{~h}$ and then subjected to XRD and TG analysis. After treatment, the weight of the treated catalysts was significantly larger than that of the reduced catalysts, suggesting that some carbon formed on the catalysts. As presented in Fig. 2, the diffraction peaks of $\mathrm{La}_{2} \mathrm{O}_{2} \mathrm{CO}_{3}$ were detected in all of the treated samples. Apparently, $\mathrm{La}_{2} \mathrm{O}_{2} \mathrm{CO}_{3}$ was formed by a reaction between $\mathrm{La}_{2} \mathrm{O}_{3}$ and $\mathrm{CO}_{2}\left(\mathrm{La}_{2} \mathrm{O}_{3}+\mathrm{CO}_{2} \rightarrow \mathrm{La}_{2} \mathrm{O}_{2} \mathrm{CO}_{3}\right)$. This suggests that carbon deposition occurred with the formation of $\mathrm{CO}_{2}$ via $\mathrm{CO}$ disproportionation, which agreed with other reports findings. ${ }^{30,31}$ No diffraction peaks corresponding to graphitic carbon were detected, indicating that the carbon remained amorphous or had a very small particle size. Fig. 7 shows the TG profiles of the treated catalysts in air after treatment. Large weight losses were observed for all of the catalysts, especially for $\mathrm{LN}-2$, whose weight loss reached $70 \%$. These weight losses can be attributed to the removal of deposited carbon. The largest weight loss (LN-2) was due to the high content of $\mathrm{Ni}$ in the $\mathrm{LN}-2$ system than in the other catalysts systems. This result further demonstrated that large amounts of carbon formed on the catalysts in a $\mathrm{H}_{2} / \mathrm{CO}$ mixture with high partial pressure of $\mathrm{CO}$, which caused catalyst activation and degradation in cell performance.

The structures of the deposited carbon on the treated catalysts in the $\mathrm{H}_{2} / \mathrm{CO}$ atmosphere was then further studied by $e x$ situ Raman analysis. Fig. 8 shows the Raman spectra of the three catalysts after treatment. Three main peaks at 1348, 1585 and $2690 \mathrm{~cm}^{-1}$ were observed, which could be assigned to the D-band, G-band and 2D band of carbon, respectively. ${ }^{32}$ According to the literature, the G-band is the main fundamental


Fig. $5 \mathrm{I}-\mathrm{V}$ curves of the conventional $\mathrm{H}^{+}$-SOFC and layered $\mathrm{H}^{+}$-SOFC at $700{ }^{\circ} \mathrm{C}$ under (a) $\mathrm{H}_{2}$ and (b) $\mathrm{CH}_{4}-\mathrm{CO}_{2}$. 

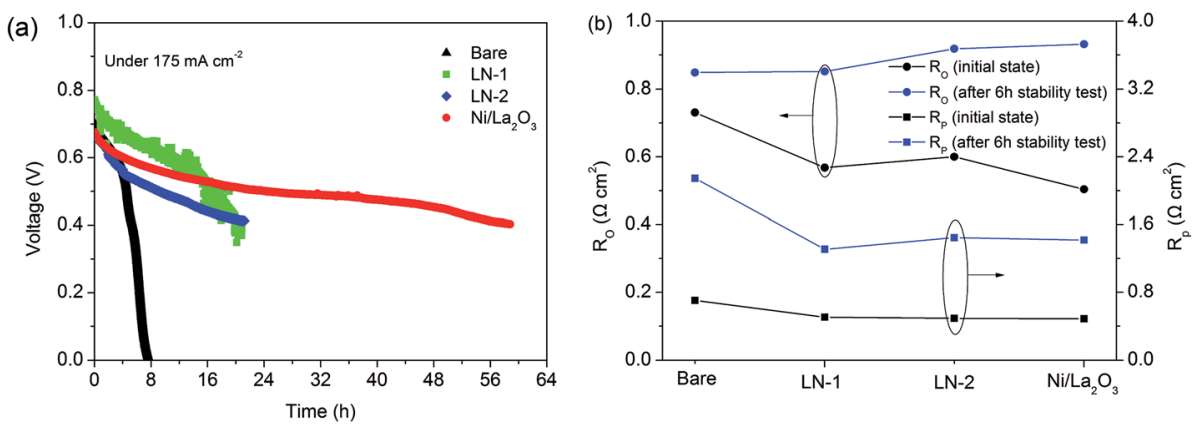

Fig. 6 (a) Time dependence of the cell voltage for the conventional $\mathrm{H}^{+}$-SOFC and layered $\mathrm{H}^{+}$-SOFC under proper constant polarization current density at $700{ }^{\circ} \mathrm{C}$ under $\mathrm{CH}_{4}-\mathrm{CO}_{2}$ mixture; (b) the ohmic resistance of electrolyte $\left(R_{\mathrm{o}}\right)$ and overpotential resistance of the electrodes $\left(R_{\mathrm{p}}\right)$ for the tested fuel cells at initial state and after stability test for 6 hours at $700{ }^{\circ} \mathrm{C}$ under $\mathrm{CH}_{4}-\mathrm{CO}_{2}$ mixture.

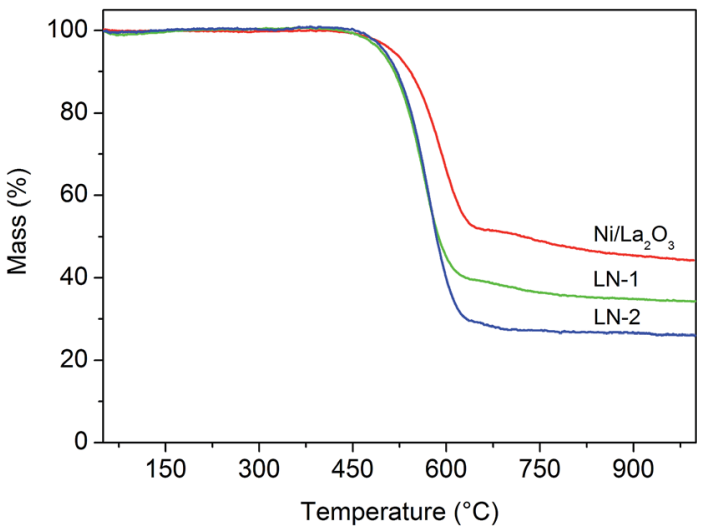

Fig. $7 \mathrm{TG}$ analysis of the reduced $\mathrm{LN}-1, \mathrm{LN}-2$ and $\mathrm{Ni} / \mathrm{La}_{2} \mathrm{O}_{3}$ catalysts after treated in $\mathrm{CO} / \mathrm{H}_{2}$ mixture gas.

peak and corresponds to the honeycomb crystalline structure of graphitic samples. The D-band is related to defects within this structure, while the 2D band arises from a resonant interaction between the electronic structure of the carbon and any incident light. ${ }^{33}$ The $\mathrm{Ni} / \mathrm{La}_{2} \mathrm{O}_{3}$ sample had the largest $\mathrm{D}, \mathrm{G}$ and $2 \mathrm{D}$ peaks compared to the other samples, suggesting that the $\mathrm{Ni} / \mathrm{La}_{2} \mathrm{O}_{3}$ sample had the most graphitic carbon. However, the

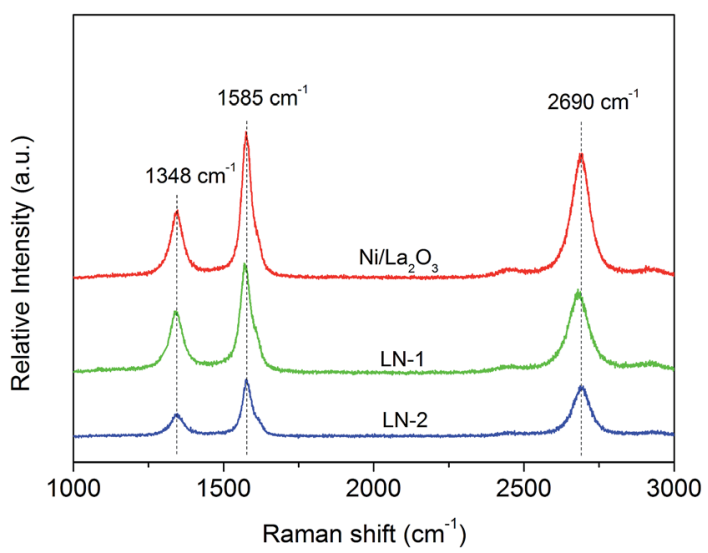

Fig. 8 Raman spectra of the treated $L N-1, L N-2$ and Ni/La $\mathrm{O}_{3}$ samples after exposed to $\mathrm{CO} / \mathrm{H}_{2}$ mixture. graphitization degree of carbon is usually expressed by the intensity ratio of $\mathrm{D} / \mathrm{G}$ and is reported to be typically less than 1.0. ${ }^{34,35}$ After our calculations, very similar values of $\mathrm{D} / \mathrm{G}$ were found: 1.10, 1.17 and 1.13 over the treated LN-1, LN-2 and $\mathrm{Ni} / \mathrm{La}_{2} \mathrm{O}_{3}$ at $700{ }^{\circ} \mathrm{C}$, respectively. This strongly suggested that carbon was mainly in an amorphous state in the treated catalysts, which agreed well with the XRD results.

\section{Conclusion}

Layered $\mathrm{H}^{+}$-SOFC has demonstrated to exhibit power consumption advantage. In the anode compartment, methane is internally dry reformed by carbon dioxide and hydrogen-rich products are produced. The electrochemical reaction occurs at the three-phase boundaries (TPB) of both electrodes by consuming hydrogen produced, producing proton flow through the electrolyte and electron across the electrodes. Electrical energy is hence produced associated with heat generation during the process. The heat generated is partly used to dry reforming of methane, partly dissipated to the environment. In this study, layered $\mathrm{H}^{+}$-SOFC with a $\mathrm{Ni} / \mathrm{La}_{2} \mathrm{O}_{3}$ catalyst layer derived from $\mathrm{La}_{2} \mathrm{NiO}_{4}, \mathrm{LaNiO}_{3}$ and $\mathrm{Ni} / \mathrm{La}_{2} \mathrm{O}_{3}$ precursors was prepared for an in situ $\mathrm{CO}_{2}-\mathrm{DRM}$ reaction. Although better cell performance was obtained for all of the layered $\mathrm{H}^{+}$-SOFC than for the conventional $\mathrm{H}^{+}$-SOFC, a large amount of carbon deposition was observed on the layered $\mathrm{H}^{+}$-SOFC after the durability test. As a result, the catalytic activities for the layered catalysts decreased and cell performance of the layered $\mathrm{H}^{+}$-SOFC was degraded. Further investigation demonstrated that $\mathrm{CO}$ disproportionation occurred in an exhaust gas with a high partial pressure of $\mathrm{CO}$, leading to deposition of amorphous carbon onto the reduced catalyst. The present study revealed that the carbon deposition properties of the catalyst layer in a $\mathrm{H}_{2}-\mathrm{CO}$ exhaust gas with a high partial pressure of $\mathrm{CO}$ should be considered when exploring a potential catalyst for the layered $\mathrm{H}^{+}$-SOFC for the $\mathrm{CO}_{2}^{-}$ DRM reaction. However, because the accumulated carbon is amorphous, regeneration of the catalyst should be feasible. In our future work, we will focus on the regeneration of these catalysts.

\section{Conflicts of interest}

There are no conflicts to declare. 


\section{Acknowledgements}

This work was supported by National Natural Science Foundation of China (51502001 \& 51572001), Natural Science Fund of Anhui Province (1608085MB31), Provincial Natural Science Research Program of Higher Education Institutions of Anhui Province (KJ2015A0501), Anhui University Personnel Recruiting Project of Academic and Technical Leaders (J01006029) and the State Key Laboratory of Materials-Oriented Chemical Engineering (KL15-01).

\section{References}

1 A. Tsoukalou, Q. Imtiaz, S. M. Kim, P. M. Abdala, S. Yoon and C. R. Müller, J. Catal., 2016, 343, 208-214.

2 Z. Zhang, X. E. Verykios, S. M. MacDonald and S. Affrossman, J. Phys. Chem., 1996, 100, 744-754.

3 M. M. Nair, S. Kaliaguine and F. Kleitz, ACS Catal., 2014, 4, 3837-3846.

4 B. Hua, N. Yan, M. Li, Y.-q. Zhang, Y.-f. Sun, J. Li, T. Etsell, P. Sarkar, K. Chuang and J.-L. Luo, Energy Environ. Sci., 2016, 9, 207-215.

5 D. J. Moon and J. W. Ryu, Catal. Today, 2003, 87, 255-264.

6 G. Valderrama, M. R. Goldwasser, C. U. d. Navarro, J. M. Tatibouët, J. Barrault, C. Batiot-Dupeyrat and F. Martínez, Catal. Today, 2005, 107-108, 785-791.

7 P. Kumar, Y. Sun and R. O. Idem, Energy Fuels, 2008, 22, 3575-3582.

8 G. Goula, V. Kiousis, L. Nalbandian and I. V. Yentekakis, Solid State Ionics, 2006, 177, 2119-2123.

9 V. Kyriakou, I. Garagounis, A. Vourros, E. Vasileiou, A. Manerbino, W. G. Coors and M. Stoukides, Appl. Catal., $B, 2016,186,1-9$.

10 N. Radenahmad, A. Afif, P. I. Petra, S. M. H. Rahman, S.-G. Eriksson and A. K. Azad, Renewable Sustainable Energy Rev., 2016, 57, 1347-1358.

11 Z. Tao, Q. Zhang, X. Xi, G. Hou and L. Bi, Electrochem. Commun., 2016, 72, 19-22.

12 Y. Guo, M. Bessaa, S. Aguado, M. C. Steil, D. Rembelski, M. Rieu, J.-P. Viricelle, N. Benameur, C. Guizard, C. Tardivat, P. Vernoux and D. Farrusseng, Energy Environ. Sci., 2013, 6, 2119-2123.

13 V. Menon, A. Banerjee, J. Dailly and O. Deutschmann, Appl. Energy, 2015, 149, 161-175.

14 W. Wang, C. Su, R. Ran and Z. Shao, J. Power Sources, 2011, 196, 3855-3862.
15 T. Wan, A. Zhu, Y. Guo, C. Wang, S. Huang, H. Chen, G. Yang, W. Wang and Z. Shao, J. Power Sources, 2017, 348, 9-15.

16 X. E. Verykios, Int. J. Hydrogen Energy, 2003, 28, 1045-1063.

17 S. Therdthianwong, A. Therdthianwong, C. Siangchin and S. Yongprapat, Int. J. Hydrogen Energy, 2008, 33, 991-999.

18 M. M. Barroso-Quiroga and A. E. Castro-Luna, Int. J. Hydrogen Energy, 2010, 35, 6052-6056.

19 S. Wang, G. Q. Lu and G. J. Millar, Energy Fuels, 1996, 10, 896-904.

20 E.-h. Yang, N. Y. Kim, Y.-s. Noh, S. S. Lim, J.-S. Jung, J. S. Lee, G. H. Hong and D. J. Moon, Int. J. Hydrogen Energy, 2015, 40, 11831-11839.

21 R. Pereniguez, V. M. Gonzalez-delaCruz, A. Caballero and J. P. Holgado, Appl. Catal., B, 2012, 123, 324-332.

22 N. F. P. Ribeiro, R. C. R. Neto, S. F. Moya, M. M. V. M. Souza and M. Schmal, Int. J. Hydrogen Energy, 2010, 35, 1172511732.

23 I. Rivas, J. Alvarez, E. Pietri, M. J. Pérez-Zurita and M. R. Goldwasser, Catal. Today, 2010, 149, 388-393.

24 J. Z. Luo, Z. L. Yu, C. F. Ng and C. T. Au, J. Catal., 2000, 194, 198-210.

25 G. Sierra Gallego, F. Mondragón, J.-M. Tatibouët, J. Barrault and C. Batiot-Dupeyrat, Catal. Today, 2008, 133-135, 200209.

26 S. M. de Lima, M. A. Peña, J. L. G. Fierro and J. M. Assaf, Catal. Lett., 2008, 124, 195.

27 S. M. Lima, J. M. Assaf, M. A. Peña and J. L. G. Fierro, Appl. Catal., A, 2006, 311, 94-104.

28 K. Sutthiumporn and S. Kawi, Int. J. Hydrogen Energy, 2011, 36, 14435-14446.

29 Z.-F. Yan, R.-G. Ding, L.-H. Song and L. Qian, Energy Fuels, 1998, 12, 1114-1120.

30 Z. Zhang and X. E. Verykios, Appl. Catal., A, 1996, 138, 109133.

31 H. M. Swaan, V. C. H. Kroll, G. A. Martin and C. Mirodatos, Catal. Today, 1994, 21, 571-578.

32 J. Schwan, S. Ulrich, V. Batori, H. Ehrhardt and S. R. P. Silva, J. Appl. Phys., 1996, 80, 440-447.

33 R. C. Maher, V. Duboviks, G. J. Offer, M. Kishimoto, N. P. Brandon and L. F. Cohen, Fuel Cells, 2013, 13, 455-469. 34 A. Cuesta, P. Dhamelincourt, J. Laureyns, A. Martínez-Alonso and J. M. D. Tascón, Carbon, 1994, 32, 1523-1532.

35 M. B. Pomfret, J. Marda, G. S. Jackson, B. W. Eichhorn, A. M. Dean and R. A. Walker, J. Phys. Chem. C, 2008, 112, 5232-5240. 